Journal of Environmental Sciences (JES)

Institute of Environmental Studies and Research, Ain Shams University

Mostafa, Asmaa et al.

\title{
SYNTHESIS AND CHARACTERIZATION OF MODIFIED LIGNIN TO BE USED IN THE REMOVAL OF SOME HEAVY METALS FROM INDUSTRIAL WASTE WATER IN POWER PLANTS
}

\author{
Assmaa S. Mostafa ${ }^{(1)}$; Mostafa M. Khalil (2) and Ashraf I. Hafez ${ }^{(3)}$ \\ 1) Cairo Electricity Production Company 2) Faculty of Science, Ain Shams \\ University 3) Egyptian Electricity Holding Company
}

\begin{abstract}
A soluble lignin derivative having an amino group was synthesized by a technique based on dry method by the reaction of isolated lignin from guava leaves with thiourea. The factors affecting the nitrogen content of the produced modified lignin mainly: reaction temperature, time and sodium hydroxide concentration besides the concentration of thiouria were studied and discussed briefly.

It was concluded that higher nitrogen content of lignin derivative is obtained at reaction temperature $90^{\circ} \mathrm{C}$ for reaction time 90 minute. Moreover increasing the amount of thiourea was accompanied by an increase in nitrogen content until a certain ratio. Product obtained was characterized by FT-IR, Thermo gravimetric analysis TGA, elemental analysis $(\mathrm{C}, \mathrm{H}, \mathrm{N}$, and $\mathrm{S})$. Nevertheless, the adsorption efficiency of metal ions as $\mathrm{Zn}, \mathrm{Cu}, \mathrm{Ni}, \mathrm{Cd}$, $\mathrm{Co}, \mathrm{V}$ and $\mathrm{Fe}$ was determined using atomic absorption spectrometry (AAS). The flocculation performance of the obtained modified lignin was evaluated in terms of turbidity, organic matter, total hardness and total silica. It was observed that the best clarification doses were at $26 \mathrm{ppm}$ ferric chloride and $4 \mathrm{ppm}$ modified lignin. This combined dose gives the lowest values of turbidity, total alkalinity, organic matter and total silica which changed from (18.2 NTU, 121ppm, 17.3ppm and 21.8ppm) to (0.97 NTU, 107ppm, $10.89 \mathrm{ppm}$ and $7.15 \mathrm{ppm})$ respectively.


It was found also that the modified lignin has high efficiency for removal of elements. For instance, as much as $75 \%$ of $\left(\mathrm{Ni}^{2+}, \mathrm{Zn}^{2+}, \mathrm{Co}^{2+}, \mathrm{Cd}^{2+}, \mathrm{Mn}^{2+}\right)$ were removed by using $(8 \mathrm{ppm})$ of modified lignin, and $95 \%$ removal of (Fe and $\mathrm{Cu}$ ).

Key words: lignin, flocculants, heavy metal removal, water treatment.

\section{INTRODUCTION}

The nature and characteristics of pollutants in water are important in determining the type of the treatment process required for their removal. The size of the particles is another very important characteristic because size determines to a large extent the type of treatment process that can be applied (Fanta et al., 1970).

Flocculants are the materials, which are used in fast solid liquid separations by an aggregation process of colloidal particles; the process is termed as flocculation. Commercial forms of synthetic flocculants may contain toxic monomers from the synthesis and additives. In many countries, the disposal of flocculated sludge with polyacrylamide derivatives has been limited and will be strictly prohibited (Guo et al., 2006 and Hao et al., 2007). An important member of renewable primary products such as cellulose, starch and chitosan, especially low-cost starch, are alternatives to synthetic flocculants (Hafez, 2014; Alkadi, 2015; El-Kareish, 2018). In recent years, considerable attention has been paid on natural materials as flocculants and chelating agents to remove heavy metals (Heinze et al., 2004; Jacrnstrocm et al., 1995 and Pal et al., 2005). 
Journal of Environmental Sciences (JES)

Institute of Environmental Studies and Research, Ain Shams University

Mostafa, Asmaa et al.

Treatment of industrial wastewater is challenging due to the variation of contaminants. A careful assessment for the types of contaminants can help in an efficient treatment. Industrial wastewater is classified according to their physical, chemical and biological characteristics (Abdel Wahab et al. 2018; Ismail et al. 2019 and El Sayed et al., 2016). More often, a complex industrial waste is introduced that is hard to be treated by simple methods. Yet, the most hazardous industrial contaminants are heavy metals. Once heavy metals enter food chain they accumulate causing serious diseases (Babel and Kurniawan, 2003). Not only heavy metals but also oil and greases act as a source of water pollution. Although it may be assumed that using water for heating or cooling may not affect water quality, water coming out of cooling or heating cycle damage the aquatic life and water quality. Oil and grease (organic matters) come out with cooling or heating wastewater. The oil and grease cause oxygen depletion. Oil and grease form a thin layer that prevents oxygen from getting to water plants and animals thus killing them. Phosphorus and nitrogen both also participate in water contamination. The increase of phosphorous and nitrogen levels lead to increase in nutrients. Increasing level of nutrients speeds up the growth rate of water plants such as algae. The large quantities of algae consume the oxygen in water causing a devastating effect on fish and other living organisms. Although in many countries, the regulation enforces the treatment of industrial wastewater, most methods used are either inefficient or expensive (Ali and Gupta, 2006). Scientists investigated more economical and efficient methods. They stated that the 
Journal of Environmental Sciences (JES)

Institute of Environmental Studies and Research, Ain Shams University

Mostafa, Asmaa et al.

combined treatment components can offer better and more efficient pathways in water treatment. Scientists search for natural materials that cost effective and ecofriendly (Crini, 2006). Natural materials such as chitosan, mineral silicate and clay have been introduced as effective materials in the treatment of industrial wastewater (Sanchez et al., 1999).Natural clay showed to be effective in the removal of some contaminants such as many heavy metals (Veli and Alyuz, 2007). Biopolymers or renewable polymers such as cellulose, lignin, starch, pectin and chitin are the abundantly available polymers in environment in the form of plant biomass or other biological sources. Serious studies have been therefore accepted to develop more effective and low-cost metal adsorbents. Materials include industrial or agricultural waste products such as unwanted slurry fly ash (Gupta et al., 1999 and Wang et al., 2004) lignite (Mohan et al., 2006) pine bark (Al-Asheh et al., 1997 and Goheen et al., 1978) peat (McKay et al., 1997) have studied the presentation of low-cost adsorbents for heavy metal removal from polluted water and analyzed for many years and still continues (Gabaldon et al., 1996 and Kadirvelu et al., 2000). Quiet, there are experiments to cultivate new organizations or improved processes for well-organized economic utilization as well as transformation of these biopolymers. Lignin sulfonation is the most deliberate reaction in lignin chemistry since it was the initial and cheapest way to make commodity (Suhas et al., 2010). The lignosulfonates are the most extensively used lignin product in industries for well drilling; cement manufacture, formulation, and pouring; ceramics manufacturing; and 4 
Journal of Environmental Sciences (JES)

Institute of Environmental Studies and Research, Ain Shams University

Mostafa, Asmaa et al.

construction materials. Both lignins and lignosulfonates are used to organize oil (Rogers, 1963; King et al., 1960 and Morton et al., 1996). In a biodegradation study, the particular lignocellulosics illustrate highest lignin content in coir pith (37\%) followed by P. juliflora (23\%) and L. camara (22\%). Though, Oscillatoriaannae treated lignocellulosics confirm maximum reduction of lignin content in L. camara (18.2\%) followed by P. juliflora $(17.4 \%)$ and coir pith (16.9\%) after 30 days of incubation was re-evaluate the literature on lignin as a biosorbent. (Srivastava., 1994) obtained extremely high uptake of $\mathrm{Pb}$ (II) and $\mathrm{Zn}$ (II), up to 1587 and $73 \mathrm{mg} / \mathrm{g}$ for $\mathrm{Pb}$ (II) and $\mathrm{Zn}$ (II), respectively, by using lignin extracted from black liquor. (Demirbas et $a l ., 2004$ ) reported a maximum adsorption competence of $8.2-9.0 \mathrm{mg} / \mathrm{g}$ for $\mathrm{Pb}$ (II) and $6.7-7.5 \mathrm{mg} / \mathrm{g}$ for $\mathrm{Cd}$ (II) on lignin from beech and poplar wood personalized by alkaline glycerol delignification (Moreno-Castilla et al., 2004). From the above data and the review, there are significant variations in the metal sorption capability of different types of lignin. Also, the interconnected mechanisms of metal sorption by lignin are still subject to debate. Several studies have originated that ion-exchange mechanisms may be accountable for the sorption of metal ions on lignin (Crist et al., 2003). Mohan et al., 2006 suggested that no single mechanism could explain the $\mathrm{Zn}(\mathrm{II})$, respectively, by using lignin extracted from black liquor reported a maximum adsorption capacity of $8.2-9.0 \mathrm{mg} / \mathrm{g}$ for $\mathrm{Pb}$ (II) and $6.7-7.5 \mathrm{mg} / \mathrm{g}$ for $\mathrm{Cd}(\mathrm{II})$ on lignin from beech and poplar wood modified by alkaline glycerol delignification (Oubagaranadin et al., 2009). 
This investigation was introducing to give some modified agriculture wastes to be used in the treatment of wastewater.

\section{EXPERIMENTAL}

Chemicals: Guava leaves as a natural waste product was supplied from local farms, Commercial Thiourea., Sodium hydroxide was supplied by Spectrum, Hong Kong. Ethyl Alcohol was supplied by Adwic, German.,The other chemicals used for analysis of water were of analytical grade.

Source of wastewater: Air preheater washing water in power plants is collected in industrial wastewater basin. This wastewater contains many pollutants and used as source of industrial wastewater in this work.

Table (1): Specifications of the industrial wastewater

\begin{tabular}{|c|c|}
\hline Parameters & Specifications \\
\hline $\mathrm{pH}$ & 2.5 \\
\hline Conductivity $(\mu \mathrm{S})$ & 1357 \\
\hline Turbidity (NTU) & 40.5 \\
\hline Total dissolved solids (mg/l) & 10610 \\
\hline Total hardness (mg/l) as $\mathrm{CaCO}_{3}$ & 1097.5 \\
\hline Partial alkalinity (mg/l) as $\mathrm{CaCO}_{3}$ & 0 \\
\hline Total alkalinity (mg/l) as $\mathrm{CaCO}_{3}$ & 167 \\
\hline Calcium hardness (mg/l) as $\mathrm{CaCO}_{3}$ & 551.5 \\
\hline Magnesium hardness (mg/l) as $\mathrm{CaCO}_{3}$ & 546 \\
\hline Organic matter (mg/l) as $\mathrm{KMnO}_{4}$ & 90.2 \\
\hline COD (mg/l) & 22 \\
\hline BOD (mg/l) & 11 \\
\hline Ammonia, $(\mathrm{mg} / \mathrm{l})$ as NH & 14.78 \\
\hline Oil and Grease (mg/l) & 13.55 \\
\hline Colloidal silica (mg/l) & 27 \\
\hline
\end{tabular}


Cont. Table (1): Specifications of the industrial wastewater

\begin{tabular}{|c|c|}
\hline Parameters & Specifications \\
\hline Chloride ion $(\mathrm{mg} / \mathrm{l})$ & 28 \\
\hline $\mathrm{Fe}(\mathrm{mg} / \mathrm{l})$ & 106 \\
\hline $\mathrm{Cu}(\mathrm{mg} / \mathrm{l})$ & 6.6 \\
\hline $\mathrm{Zn}(\mathrm{mg} / \mathrm{l})$ & 40 \\
\hline $\mathrm{Ni}(\mathrm{mg} / \mathrm{l})$ & 40 \\
\hline $\mathrm{Cd}(\mathrm{mg} / \mathrm{l})$ & 17 \\
\hline $\mathrm{Mn}(\mathrm{mg} / \mathrm{l})$ & 12 \\
\hline $\mathrm{Co}(\mathrm{mg} / \mathrm{l})$ & 13 \\
\hline $\mathrm{V}(\mathrm{mg} / \mathrm{l})$ & 105 \\
\hline
\end{tabular}

Testing and analysis: All series of water examination and chemical analysis were carried out according to the standard method of (ASTM Book of Standards, I, II 2001).

Infrared Analyses: A Fourier transform infrared system (FTIR), JASCO FTIR 4110 spectrometer Japan, was used. Samples were prepared using the $\mathrm{KBr}$ disc technique. The infra, red absorption spectra were recorded in the region of $4000-400 \mathrm{~cm}^{-1}$.

Jar test: Simulation of clarification applying Jar test method is considered the most applicable way to permit the comparison of various chemicals combination for determining the optimum chemical program was applied. The jar test method contains a set of six beakers (1liter) in conjugation with multiple stirrers. Each beaker was filled with one liter of wastewater and stirred at $100 \mathrm{rpm}$. The different doses of coagulant were added rapidly and stirred for 3 minutes. The stirring rate was then reduced to 50 and $20 \mathrm{rpm}$ for a time of 5 and 10 minutes respectively to allow complete flock formation, 
Journal of Environmental Sciences (JES)

Institute of Environmental Studies and Research, Ain Shams University

Mostafa, Asmaa et al.

and then stirring was stopped. The comparative settling rate, flock size and supernatant clarity were recorded. After a settling time of 15 minutes, $250 \mathrm{ml}$ of supernatant water were siphoned-off for further analysis.

\section{Water analysis:}

- Turbidity of water was measured in nephelometric turbidity units (NTU) using Helige digital direct reading turbidmiter.

- Organic matter of water was determined by consumption of $\mathrm{KMnO}_{4}$ in acidic solution.

- Total silica determined spectrophotometry-using spectrophotometer.

- Metal ions in water were quantified using Atomic Absorption Spectrometer, Solaar S-4 S- Series Thermo Electron Corporation UK.

- The $\mathrm{pH}$ of solutions were determined using accumet $\mathrm{pH}$ meter model 810 Fisher scientific

- Determination of removal efficiency:

- \% Removal of metal ions, were calculated from the following formula:

- $\%$ Removal $=\mathrm{C}_{0}-\mathrm{C} / \mathrm{C}_{0} \times 100$

Where, $\mathrm{C}_{0}$ and $\mathrm{C}=$ metal ion concentration, organic matter and turbidity of wastewater before and after coagulation treatment by corncobs derivative, respectively.

Thermogravimetric Analysis (TGA): Thermogravimetric analysis of extracted and modified lignin was performed with Thermo gravimetric analyzer Lecco: Mac-500.ST. Joseph. Michigan-USA. This apparatus 
Journal of Environmental Sciences (JES)

Institute of Environmental Studies and Research, Ain Shams University

Mostafa, Asmaa et al.

provides a continuous measurement of sample weight at a range of temperatures between ambient and $600{ }^{\circ} \mathrm{C}$. The samples were heated in an alumina cell to $600^{\circ} \mathrm{C}$ at heating rate of $10^{\circ} \mathrm{C} / \mathrm{mm}$ with nitrogen as the circulating gas.

Elemental analysis (C.H.N, and S): The elemental analysis of lignin and modified lignin $(\mathrm{C}, \mathrm{H}, \mathrm{N}$, and $\mathrm{S})$ determined by Leco Truspect $(\mathrm{CHN})$ Analyzer, Leco Corporation 3000 LAKE View AVE.ST. Joseph, MI- USA. lignin isolation by the ( $\mathbf{N a O H}$ ) method: The $\mathrm{NaOH}$ method of (Anwar et $a l ., 2004)$ was carried out for the isolation of lignin from guava leaves. The guava leaves (20 g) was grinded and sieved in $200-\mu \mathrm{m}$ mesh. The grinded guava leaves was mixed for $3 \mathrm{~h}$ at $90^{\circ} \mathrm{C}$ with $8 \%$ aq. $\mathrm{NaOH}(50 \mathrm{~mL})$ and the slurry filtered. The filtrate was centrifuged for $20 \mathrm{~min}$, the supernatant was collected, evaporated and dried. The dried sediment was washed twice with distilled water $(50 \mathrm{~mL})$ and centrifuged. The residue was suspended in water and adjusted to $\mathrm{pH} 7$ by adding $(1 \mathrm{M})$ hydrochloric acid, and the slurry was centrifuged as lignin. The lignin washed three times with acetone and filtered. The filtrated lignin dried in a convection oven at $40{ }^{\circ} \mathrm{C}$ for $48 \mathrm{~h}$. The produced lignin was weighted in an analytical balance with production yield of $2 \mathrm{gm}$.

Preparation of modified lignin: 10 gram of lignin as obtained from lignin isolation step with different concentration of thiouria mainly $(1,2,3,4,5$ and 6 gm.) were grinded. The mixtures were heated to a melt until gas was evolved for with intermittent stirring. These mixtures were mixed with $2 \mathrm{ml}$ of Vol.(49); Iss.(8); No.(1); August 2020 
Journal of Environmental Sciences (JES)

Institute of Environmental Studies and Research, Ain Shams University

Mostafa, Asmaa et al.

different concentration of sodium hydroxide solutions $(2,4,6,8$, and 10\%). Then left at different temperature from 20-160 for different time for completing the reaction. After that, the reaction was cooled to $20^{\circ} \mathrm{C}$. and 20 $\mathrm{ml}$ of water were added. It was diluted against 100 parts $\mathrm{H}_{2} \mathrm{O}$ to give $98 \%$ yield of product having different nitrogen and sulfur content (Yalpani et al., 1995).

\section{RESULTS AND DISCUSSION:}

Figure (1) shows the typical photograph of the guava leaves (waste material) that used in this work.

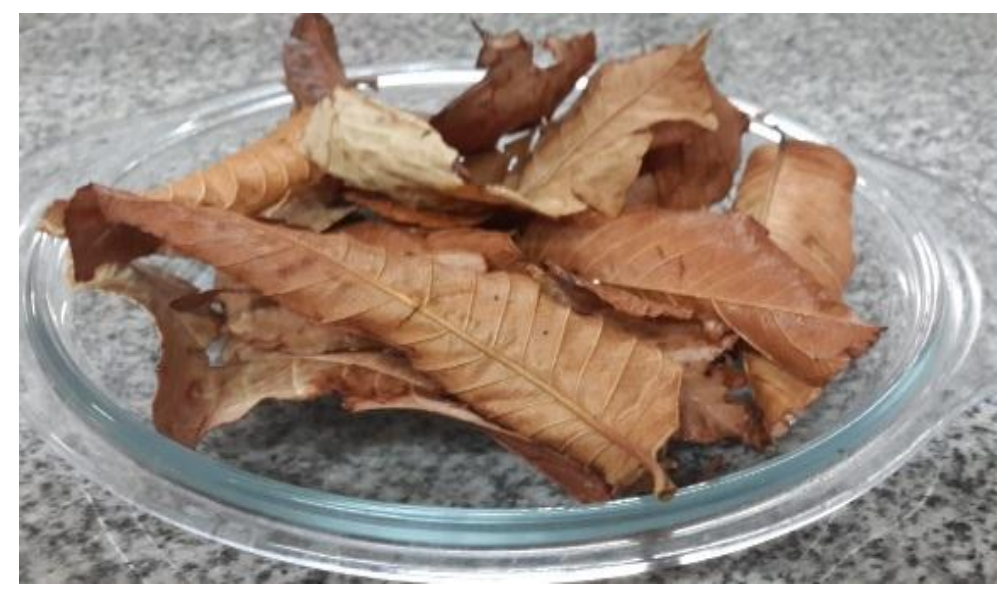

Figure (1): shows the typical photo of the guava leaves

The utilization of these waste cause minimization of potential waste disposal problems. However, agricultural waste represents an effective, cheap, biodegradable and environmentally safe for preparation of ion 
exchangers that are valuable for water treatment (Gebbie, 2006; Domard, 1996; Jeon and Höll, 2003; Guibal, 2005 and Hu, 2011).

Any agriculture products contain cellulose, hemicellulose and lignin with different percentages as shown in figure (2).

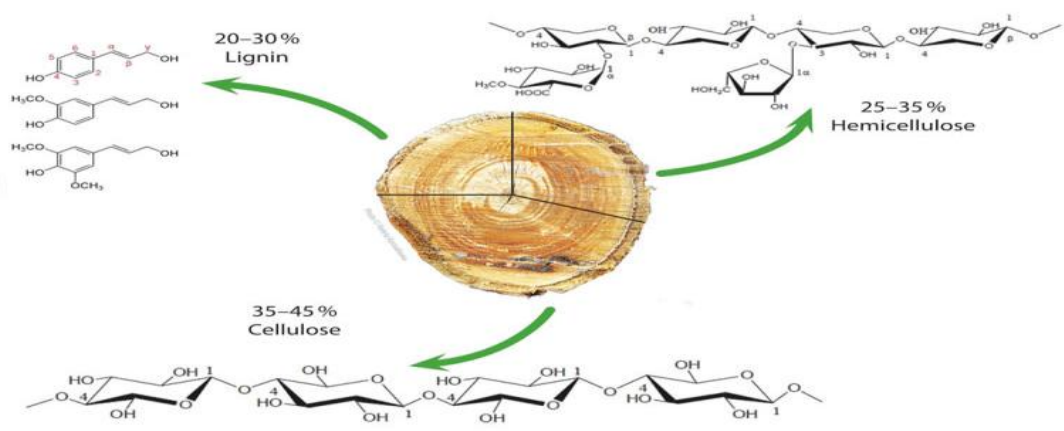

Figure (2): Chemical Structures of Cellulose, Hemicellulose and Lignin Mechanism of preparing modified lignin: Lignin is quite complex, with different structures and repeat units depending on the plant species, growing location, and growth duration (Zakzeski et al., 2010; Nada et al., 2000).

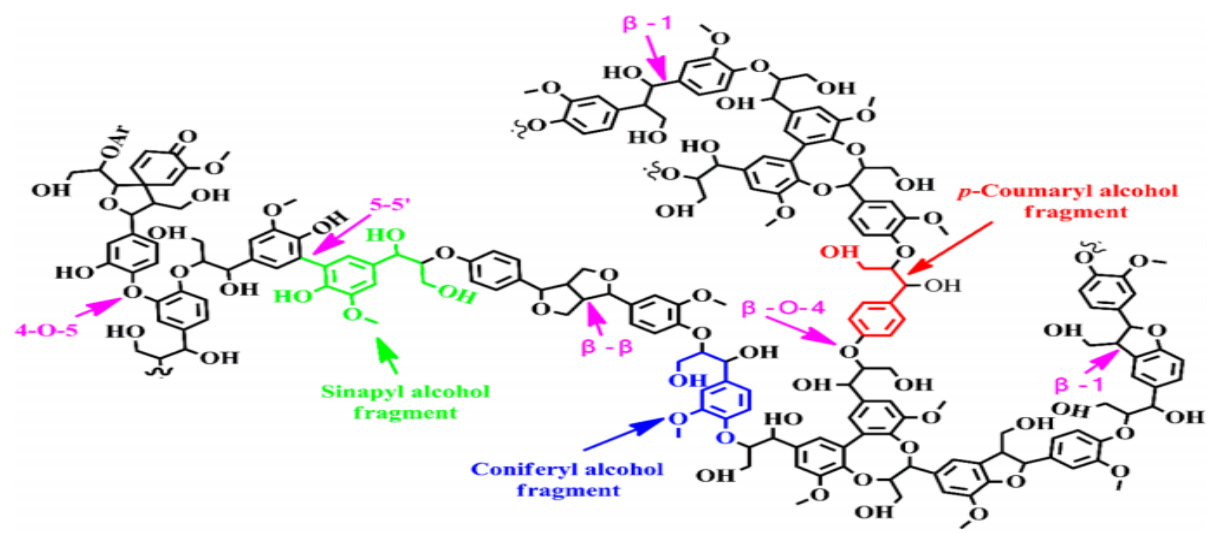

Figure (3): Structure of lignin 
Lignin can react with thiouria in alkaline media at high temperature to incorporate amino group and sulfure to the lignin backbone to form (Modified lignin) as the following reaction:
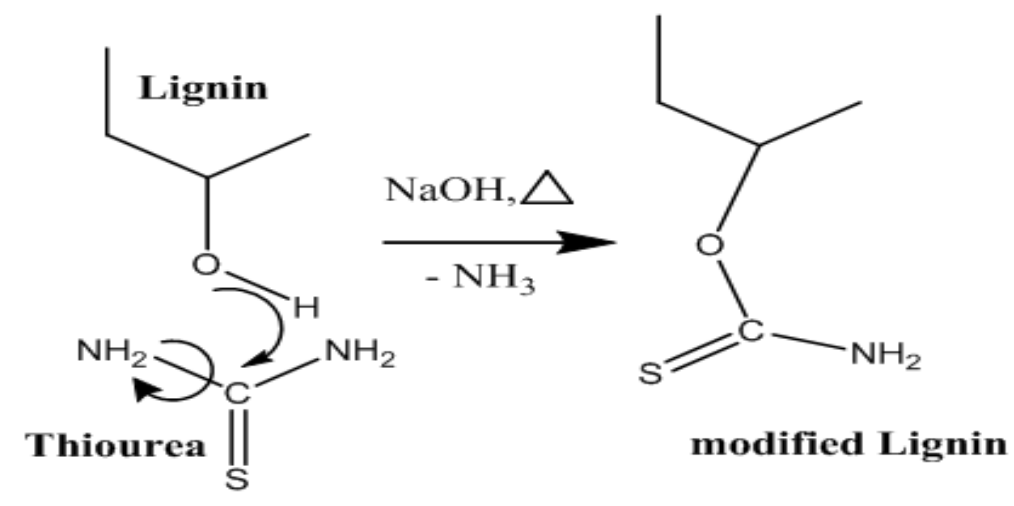

\section{Figure (4)}

The produced modified lignin has amino group which imparts the positivity character to the lignin, which acts as ion exchange material and help to remove the turbidity and metal ions from wastewater.

\section{Modified lignin investigation:}

Factors affecting reaction of thiourea and lignin: The parameters influencing reaction of thiouria and lignin, for example, time of reaction, temperature of reaction, sodium hydroxide concentration, and additionally, thiouria concentration have been investigated to decide the ideal conditions for reaction yield as nitrogen content.

Effect of temperature: The effect of temperature on the nitrogen content of the lignin derivatives as shown in figure (5) at lignin (2g), $1 \mathrm{gm}$ thiouria, 20 
min and $2 \%$ conc. of $\mathrm{NaOH}$. It is clear that the nitrogen content increases as the temperature is raised up to $120^{\circ} \mathrm{C}$. Obviously, the nitrogen content increments as the temperature is raised up to $120^{\circ} \mathrm{C}$. This may be ascribed to the fact that, the mobility of the ions and the molecules increased by raising the temperature of the subsequent in an augmentation in the rate of reaction.

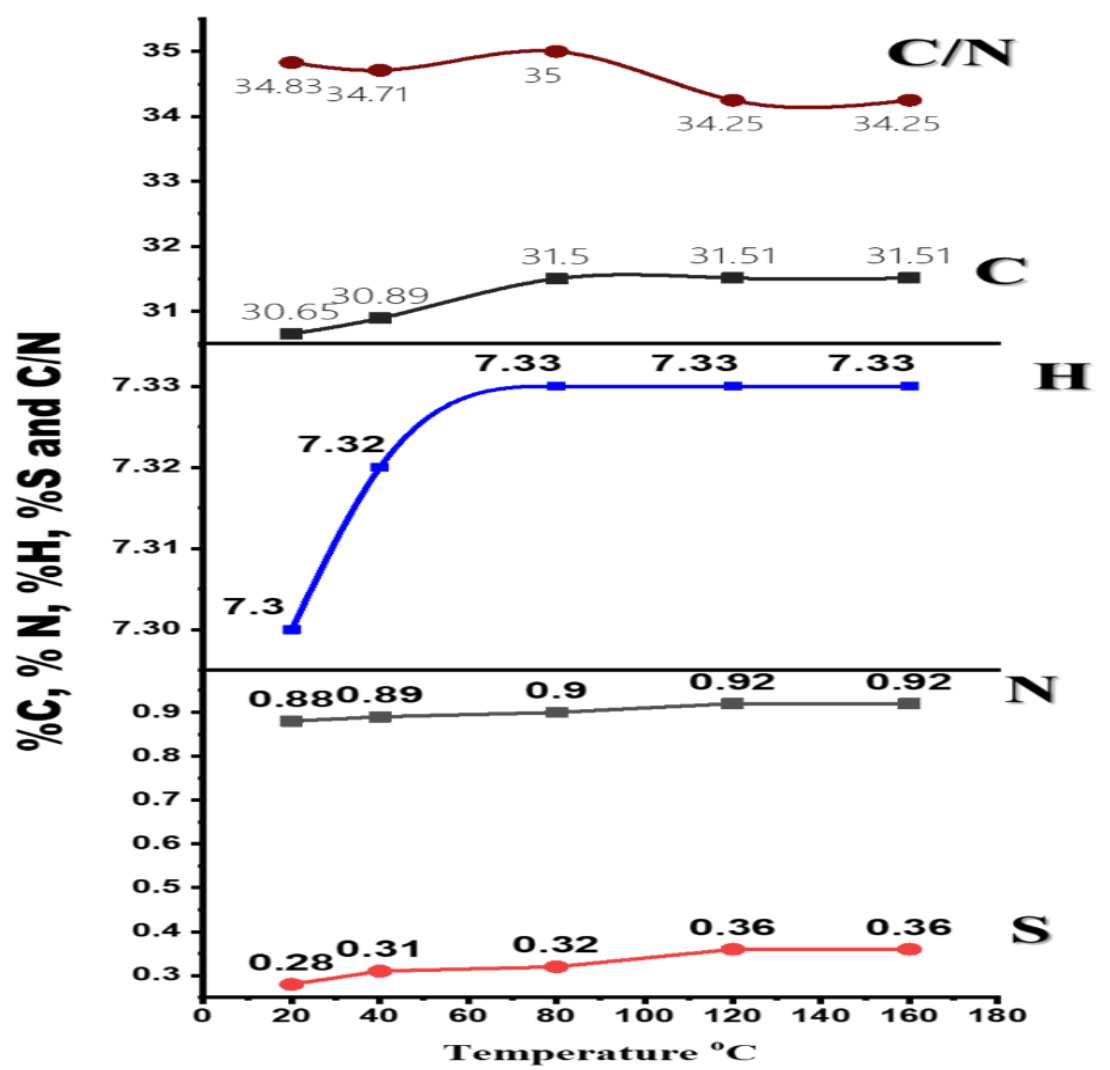

Figure (5): Effect of the temperature on the $\%(\mathrm{~N}, \mathrm{C}, \mathrm{H}, \mathrm{S}$ and $\mathrm{C} / \mathrm{N})$ of modified lignin (1gm 20 min. and 2\% conc. of $\mathrm{NaOH})$ 
Journal of Environmental Sciences (JES)

Institute of Environmental Studies and Research, Ain Shams University

Mostafa, Asmaa et al.

Effect of Reaction time: The results represented in Figure (6) shows the effect of the reaction time on the efficiency of the reacting products as nitrogen content at: $1 \mathrm{gm}$ thiouria, and $2 \%$ conc. of $\mathrm{NaOH}$. It is found that, at the chosen temperature $\left(120^{\circ} \mathrm{C}\right)$, the increase of the reaction time from 20 to $120 \mathrm{~min}$ is accompanied by an increment in the reaction rate represented by nitrogen content, and that, after $100 \mathrm{~min}$, the increment does not change. The sulfur values kept constant at $0.36 \%$.The carbon values are limited from 30.65 to 31.51 , Hydrogen values varied between 7.30 to $7.33 \%$ in same time that Nitrogen values varied between 0.88 to $0.92 \%$, which affect the carbon to nitrogen $(\mathrm{C} / \mathrm{N})$ ratio, which varied between 34.25 to 35.01 .

It may be concluded that longer reaction time leads to an increase of the reactivity of the ions and molecules in the reacting medium; hence, the activation reaction power is increased leading to greater nitrogen contents in the lignin derivative.

It might be presumed that more drawn out reaction time prompts an increase of the reactivity of the ions and molecules in the reacting medium; consequently, the actuation response control is expanded leading to more noteworthy nitrogen substance in the lignin derivatives. 


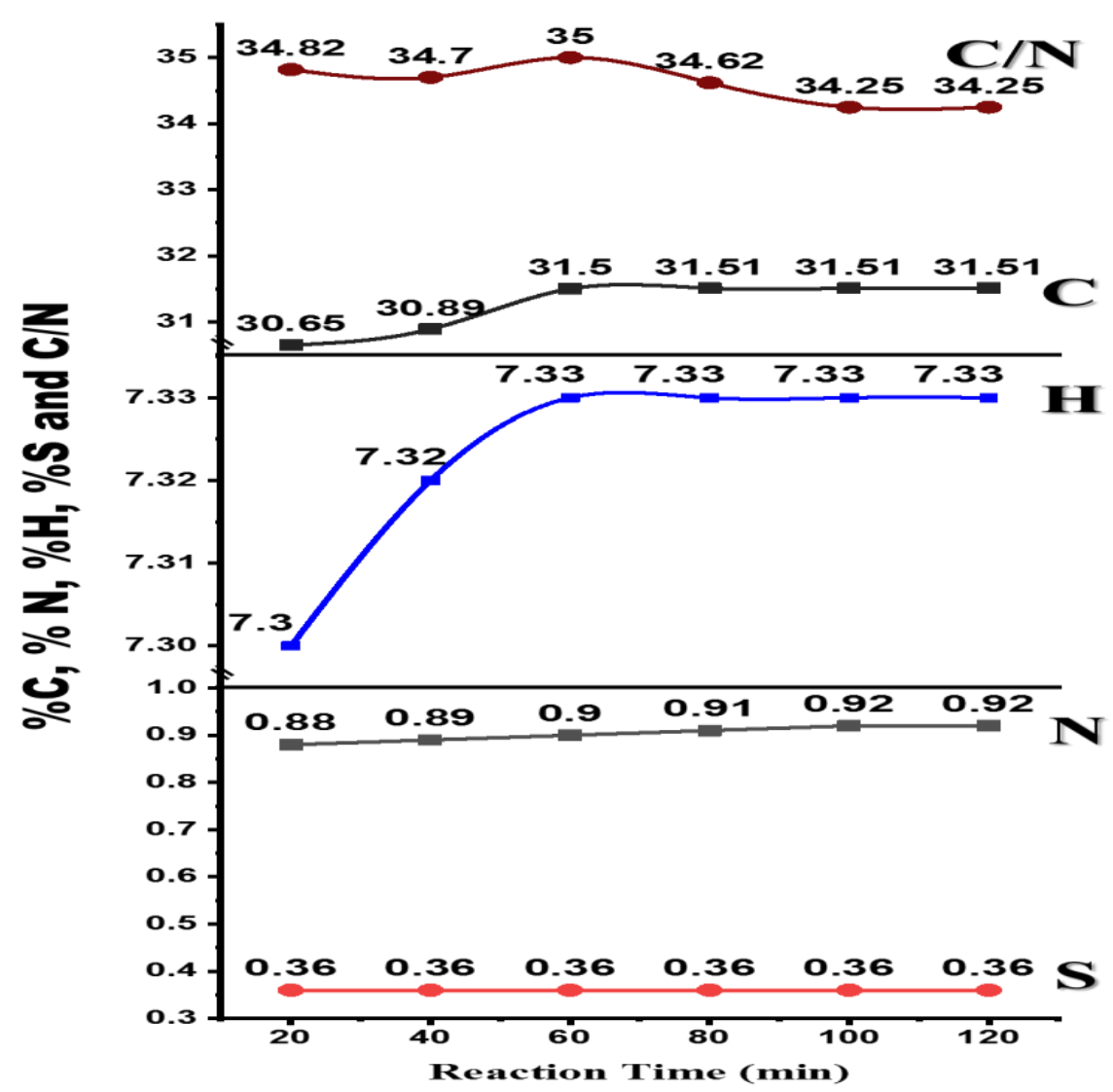

Figure (6): Effect of the reaction time on the on the $\%(\mathrm{~N}, \mathrm{C}, \mathrm{H}, \mathrm{S}$ and $\mathrm{C} / \mathrm{N})$ of lignin derivatives

Effect of sodium hydroxide concentration: Figure (7) represents the effect of $\mathrm{NaOH}$ concentration on nitrogen content in the modified lignin. For the optimum conditions of temperature $\left(120^{\circ} \mathrm{C}\right)$, reaction time $(100 \mathrm{~min})$ and $1 \mathrm{gm}$ thiouria, different concentrations of $\mathrm{NaOH}$ ranging from 2-10\% were 
examined. It is clear that, by increasing the $\mathrm{NaOH}$ concentration until $8 \%$, the nitrogen content increases to a maximum value indicating that this concentration is sufficient for complete neutralization of theuoria and lignin. Further increase of $\mathrm{NaOH}$ concentration caused no increase in the nitrogen content.

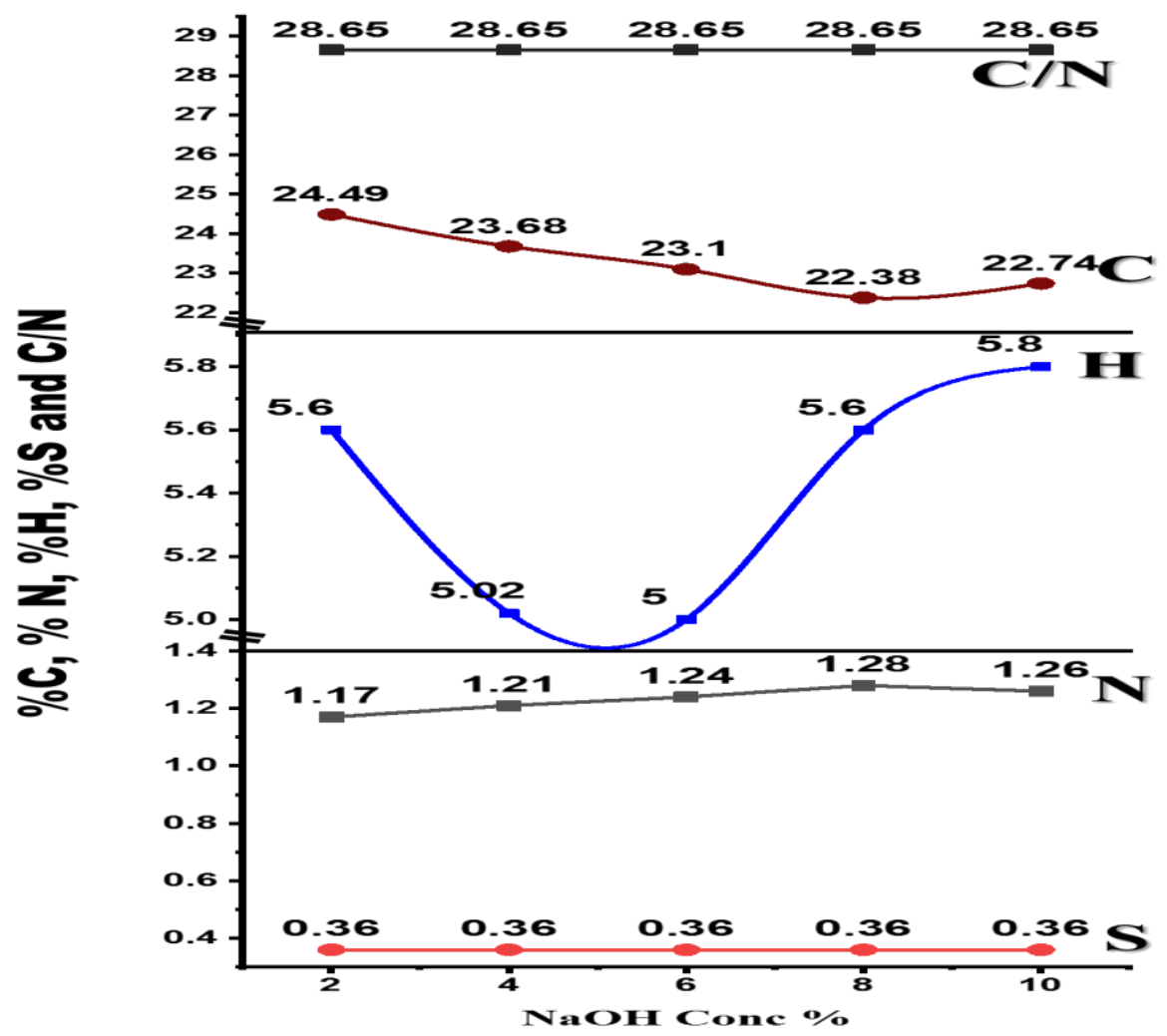

Figure (7): Effect of the $\mathrm{NaOH}$ on the nitrogen content (\%) of lignin derivatives 
Effect of thiourea concentration: Different concentration of thiouria namely $(1,2,3,4,5$ and 6 gm) were examined at the aforementioned chosen conditions with lignin. The obtained results are represented in Figure (8) which indicates that by increasing the amount of thiourea, the reaction product increases until $(5 \mathrm{gm})$ which is the better $(2.48 \%)$ then began to decrease by further increment.

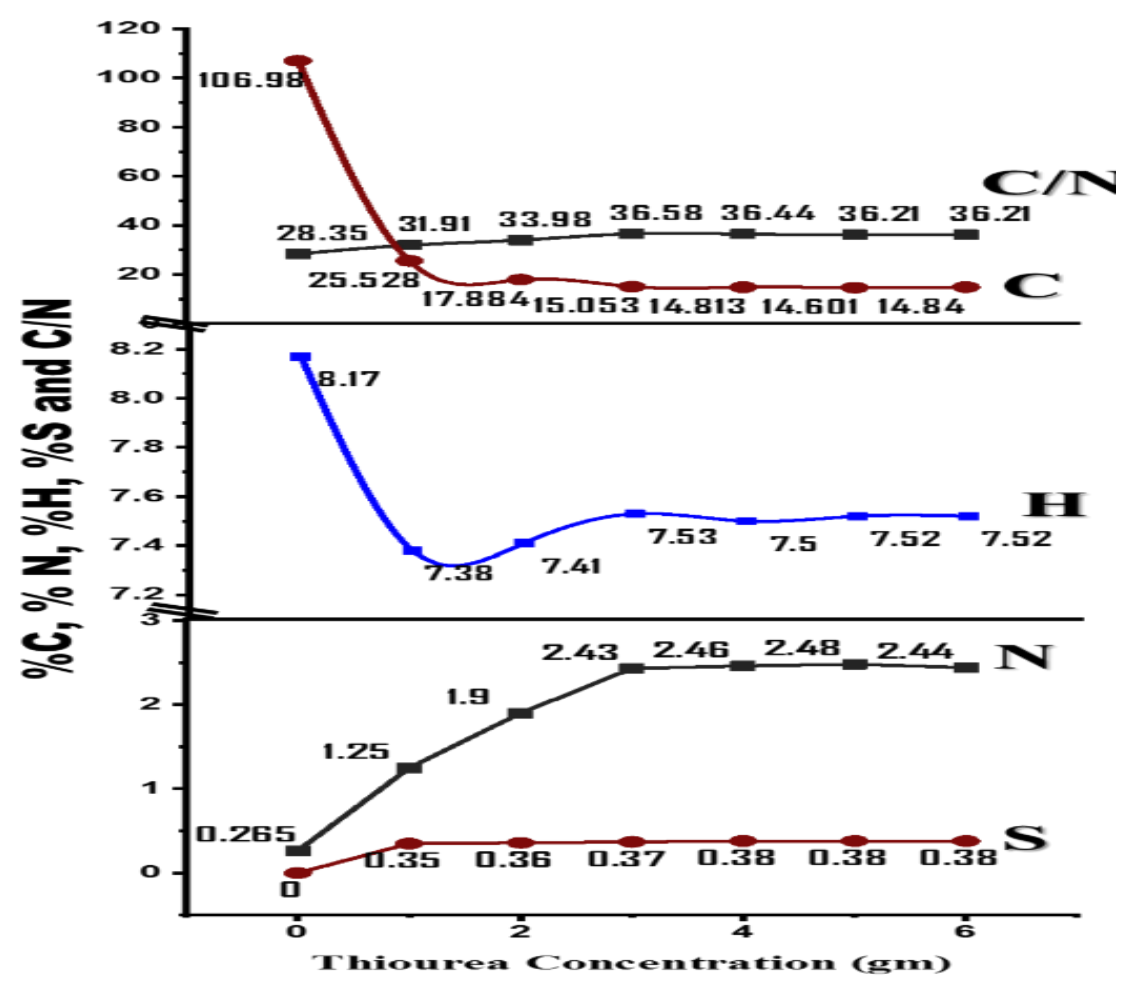

Figure (8): Effect of the thiourea concentration on the \% $(\mathrm{N}, \mathrm{C}, \mathrm{H}, \mathrm{S}$ and $\mathrm{C} / \mathrm{N}$ ) of modified lignin. 
According to nitrogen content of the aforementioned prepared modified lignin. The higher nitrogen content sample was prepared and chosen to make characterization comparison between lignin and modified lignin. Inanition to complete the work in the application of water treatment as coagulant especially in the treatment of wastewater produced from washing water of air preheater units in power station by making a comparative study between the prepared lignin derivative and ferric chloride as conventional coagulant materials. The following part shows such results for such application.

\section{Characterization of lignin and modified lignin:}

Thermogravimetric analysis (TGA): TGA is a simple and accurate method for studying the decomposition pattern and the thermal stability of the polymers. Figure (9) shows the thermo- gravimetric analysis (TGA) for lignin (blank), modified lignin, respectively.

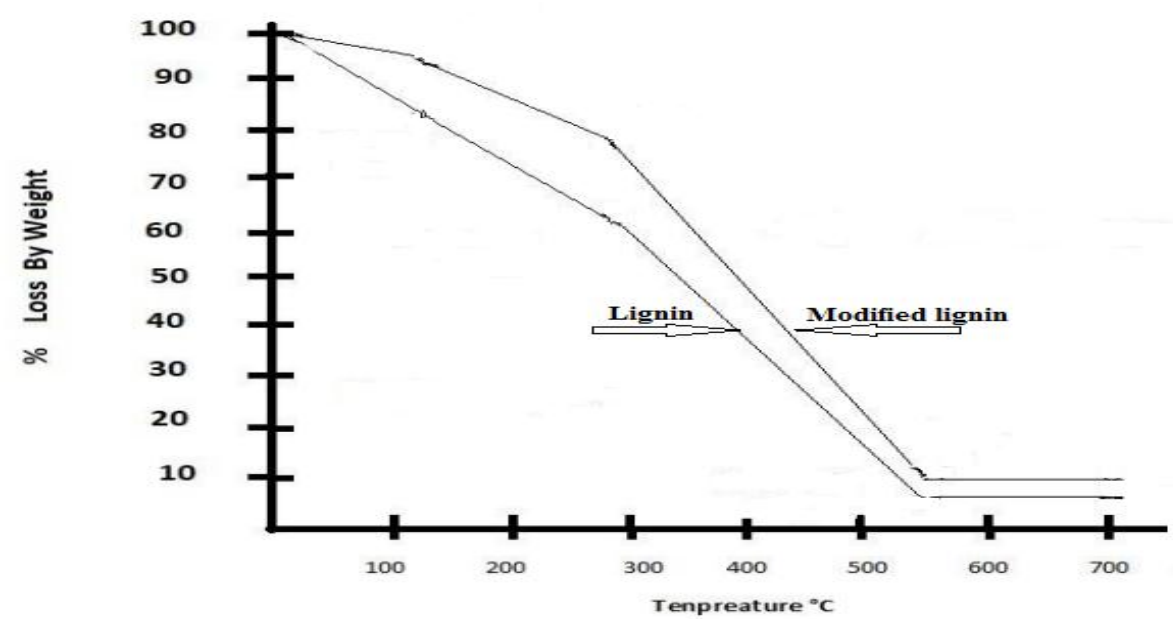

Figure (9): TGA of lignin and modified lignin. 
Journal of Environmental Sciences (JES)

Institute of Environmental Studies and Research, Ain Shams University

Mostafa, Asmaa et al.

As it obvious, the range for lignin Figure (9) demonstrates four characteristic stages for decomposition. The principal arrange begins at100 ${ }^{\circ} \mathrm{C}$ and end at $150^{\circ} \mathrm{C}$ with a weight reduction of $6 \%$. This could be perceived as due to the moisture content of lignin. The second stage, which identified with the primary decay of lignin macromolecules happens in one stage of decomposition begin at $150^{\circ} \mathrm{C}$ and end at $300^{\circ} \mathrm{C}$ with most extreme deterioration temperature of $300{ }^{\circ} \mathrm{C}$ and weight reduction of $20 \%$. The third phase of weight loss is identified with the carbonization procedure, which happens up to $550{ }^{\circ} \mathrm{C}$ with a weight reduction of $95 \%$. More increasing of temperature leads to for metal oxides with weight loss of $98 \%$. For the considered modified lignin, the primary stage begins at $100^{\circ} \mathrm{C}$ and end at $150^{\circ} \mathrm{C}$ with weight reduction of $14 \%$. The second phase of decomposition, representing the main decomposition, continues in two stages. The initial step begins at $250^{\circ} \mathrm{C}$ and end at $400^{\circ} \mathrm{C}$. The weight reduction in this step for the studied sample was $42 \%$.

This step of degradation simulates and corresponds to main degradation process recorded for lignin. This degradation, most likely, could be identified with the degradation of modified lignin. The third phase of degradation happens up to $550{ }^{\circ} \mathrm{C}$ with weight reduction of $92 \%$ for the sample. More increasing of temperature leads to for metal oxides with weight loss of $95 \%$.

Energy dispersive x-ray (EDX): The grinded lignin and lignin derivative were analyzed using energy dispersive $\mathrm{x}$-ray (EDX) and elemental analysis analyzer it has the following specifications: 
Figure (10.a) showed the X-ray analysis chart which show that the native lignin contains each of $\mathrm{C}, \mathrm{Si}, \mathrm{K}$ and $\mathrm{Ca}$ elements. Figure (10.b) showed the Xray analysis chart which show that the lignin derivative contains each of $\mathrm{C}$, Si, S, K and Ca elements.

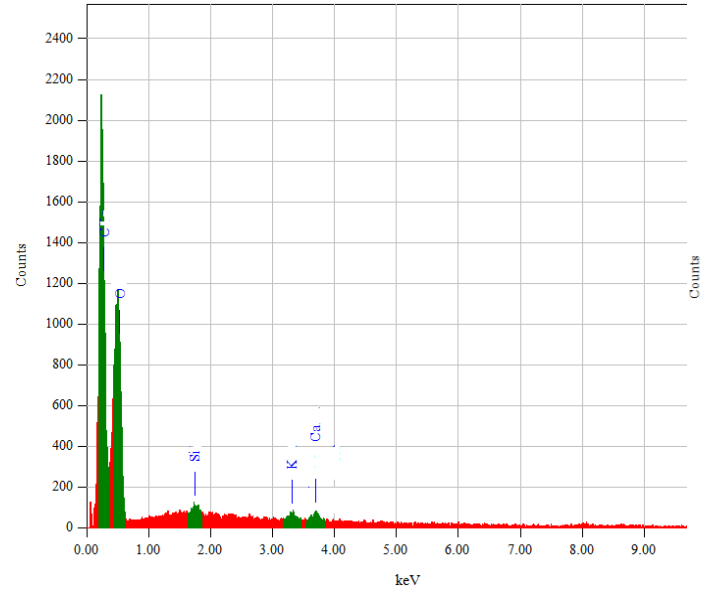

(a)

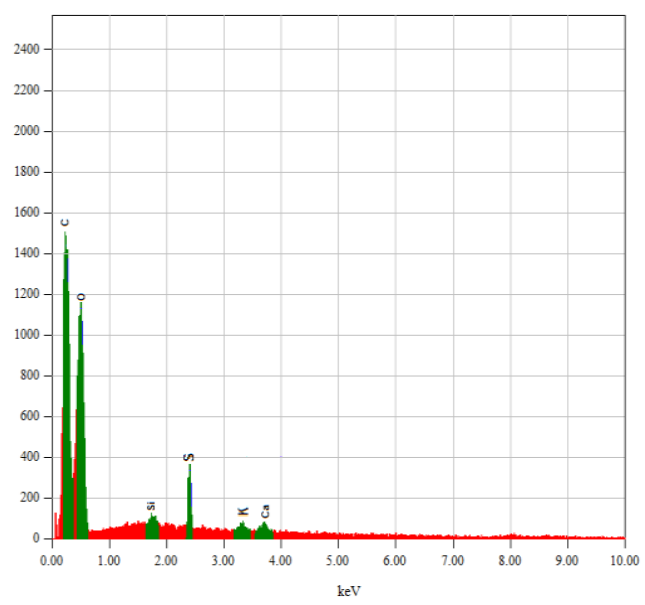

(b)

Figure (10): Energy dispersive X-ray (EDX) of lignin (a) and modified lignin (b)

Elemental analysis of raw and modified lignin: The elemental analysis of lignin and modified one are listed in table (2).

Table (2): Elemental analysis of lignin and modified lignin

\begin{tabular}{|c|c|c|c|c|c|c|c|c|c|c|}
\hline \multirow{2}{*}{ Element } & \multicolumn{4}{|c|}{ Lignin } & \multicolumn{4}{|c|}{ Modified lignin } \\
\cline { 2 - 10 } & $\mathbf{C}$ & $\mathbf{H}$ & $\mathbf{N}$ & $\mathbf{S}$ & $\mathbf{C} / \mathbf{N}$ & $\mathbf{C}$ & $\mathbf{H}$ & $\mathbf{N}$ & $\mathbf{S}$ & $\mathbf{C} / \mathbf{N}$ \\
\hline \hline Percentage & 28.35 & 5.19 & 0.75 & Nil & 37.8 & 36.21 & 7.52 & 2.44 & 0.38 & 14.84 \\
\hline
\end{tabular}




\section{FTIR of raw and modified lignin:}

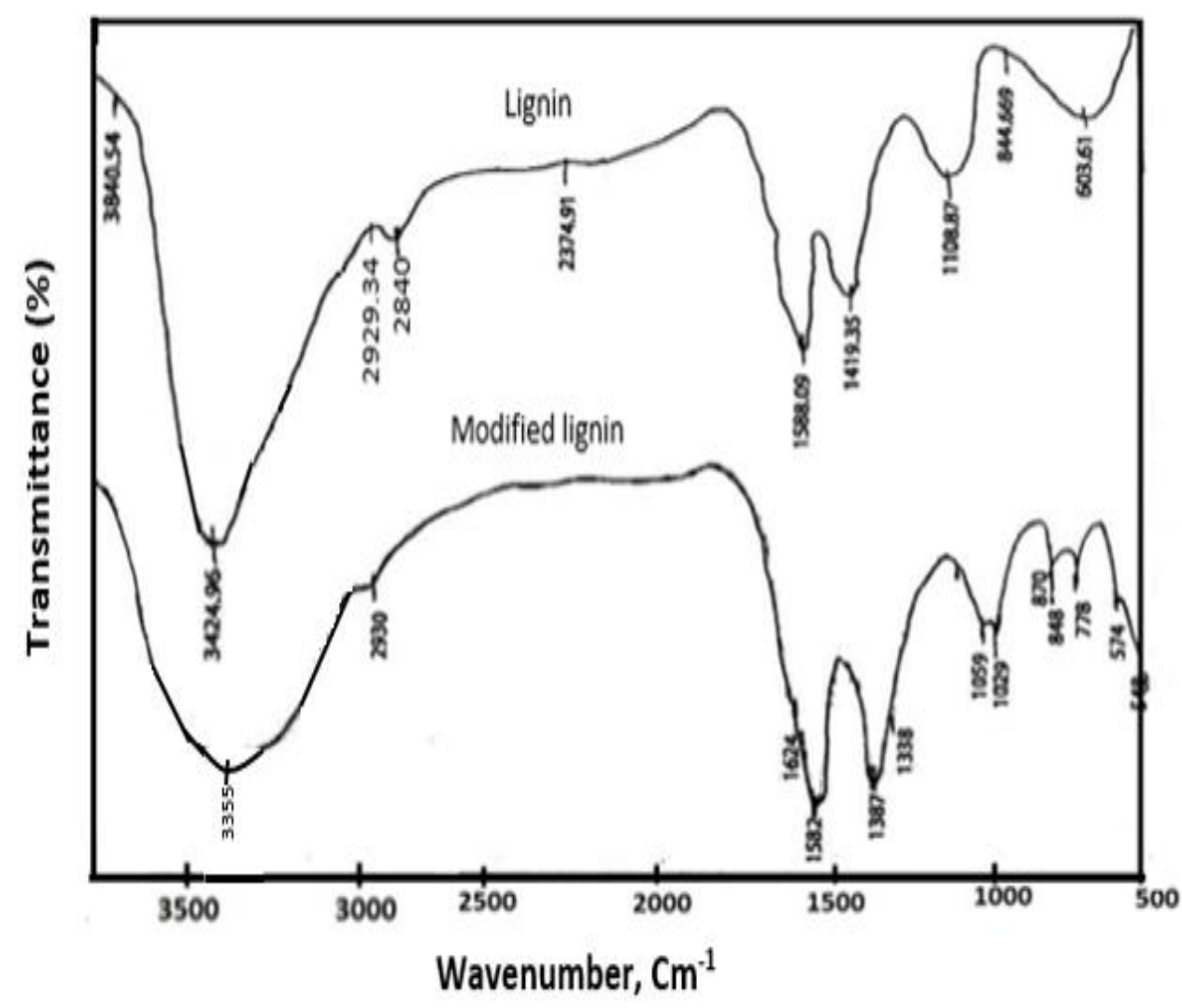

Figure (11): FTIR of raw and modified lignin

The fine powder of isolated lignin from guava leaves was investigated using FTIR technique. The investigation was conducted to identify and characterize the product by comparing the spectra of lignin and modified lignin. Thus, the FTIR spectra of the produced isolated lignin and modified one was studied to show its characteristics. It was concluded from Figure (11) 
Journal of Environmental Sciences (JES)

Institute of Environmental Studies and Research, Ain Shams University

Mostafa, Asmaa et al.

that all the peaks detected for the isolated lignin are similar to those of modified lignin and related to $\mathrm{C}-\mathrm{OH}, \mathrm{CH}, \mathrm{CH}_{2}, \mathrm{CH}_{3}$ and $\mathrm{C}=\mathrm{O}$ groups. Whereas, the FTIR spectra of pure lignin showed a peak at $3424.96 \mathrm{~cm}^{-1}$ which assigned to $\mathrm{OH}$ stretching vibration of hydroxyl group of the lignin; this peak in the modified lignin was broadened due to $-\mathrm{OH}$ and $-\mathrm{NH}_{2}$ stretching. A symmetric stretching for $\mathrm{CH}_{3}$ of methoxyl group appeared at $2840 \mathrm{~cm}^{-1}$. The band detected at $2929.34 \mathrm{~cm}^{-1}$ arises from C-H stretching in methyl and methylene group. A peak at $1713.83 \mathrm{~cm}^{-1}$ assigned to carbonyl stretching-unconjugated ketone and carboxyl groups. The peaks observed at $1588.091 \mathrm{~cm}^{-1}$ and $1419.35 \mathrm{~cm}^{-1}$ are corresponding to the aromatic skeletal vibrations, ether bond band. A small peak at $1035 \mathrm{~cm}^{-1}$ may be due to aromatic $\mathrm{CH}$ in plane deformation. On the other hand, many peaks are appeared in the modified lignin spectra such as $1624 \mathrm{~cm}^{-1}, 1338 \mathrm{~cm}^{-1}, 778 \mathrm{~cm}^{-}$ 1 and $574 \mathrm{~cm}^{-1}$.

Evaluation of modified lignin as coagulant aid: The modified lignin derivative possessing positively charged groups (amino groups) which acts as ion-exchanger. They can remove organic and inorganic matter carrying negative charge from the water. By using modified lignin for the clarification of raw water in a dose from $(2-10 \mathrm{mg} / \mathrm{l})$, the examined parameters revealed that modified lignin is able to remove turbidity, organic matter, colloidal silica, and sulfate gives better water clarity. Table (3) showed that the optimum dose that gave best result was $(6 \mathrm{mg} / \mathrm{l})$. 
Table (3): Effect of modified lignin dose on the quality of treated water

\begin{tabular}{|c|c|c|c|c|c|c|c|}
\hline \multirow{2}{*}{ Parameter } & \multirow{2}{*}{$\begin{array}{c}\text { Waste } \\
\text { water }\end{array}$} & \multicolumn{6}{|c|}{$\begin{array}{c}\text { Modified lignin dose (mg/l) } \\
\text { at 20ppm ferric chloride }\end{array}$} \\
\cline { 4 - 8 } & & $\mathbf{0}$ & $\mathbf{2}$ & $\mathbf{4}$ & $\mathbf{6}$ & $\mathbf{8}$ & $\mathbf{1 0}$ \\
\hline \hline Turbidity (NTU) & 17.4 & 2.8 & 1.9 & 1.1 & 0.8 & 0.9 & 0.9 \\
\hline Sulphates (mg/l) & 360 & 360 & 140 & 60 & 23 & 23 & 23 \\
\hline $\begin{array}{c}\text { Organic matter } \\
\left(\mathrm{mg} / \mathrm{l} \text { as } \mathrm{KMnO}_{4}\right)\end{array}$ & 19 & 8.2 & 14.29 & 12.23 & 8.29 & 8.29 & 9.29 \\
\hline $\begin{array}{c}\text { Total Silica } \\
\left(\mathrm{mg} / \mathrm{l} \text { as } \mathrm{SiO}_{2}\right)\end{array}$ & 19.5 & 18.9 & 8.26 & 7.2 & 6.1 & 6.1 & 6.1 \\
\hline
\end{tabular}

Also it is widely known that natural compounds can build complexes with certain ions such as calcium and magnesium. In addition, the creative amino sites are the main reactive groups for removal of organic matter and total silica removal from water. Therefore, a comparison was made between modified lignin and either ferric chloride as a traditional coagulant. For this purposes a simulation of clarification applying Jar test method which is considered the most applicable way to permit the comparison of various chemicals combination for determining the optimum chemical program was applied. The most important measurements in jar test are coagulation and/or flocculent dosages, flock size, settling characteristics, flock forming time, and finished water clarity.

When comparing the using of modified lignin and ferric chloride in a different dose, the examined parameters revealed that modified lignin is able to remove turbidity, organic matter and gives better water clarity. Table (3) shows that the optimum dose that gave best result was $(6 \mathrm{ppm}$ modified linin 
$+20 \mathrm{ppm} \mathrm{FeCl}_{3}$ ). While for ferric chloride $35 \mathrm{ppm}$. It is also seen that the combination of modified lignin gives the best result for removing organic matter, turbidity total hardness, calcium hardness and total silica.

The efficiency of modified lignin is due to protonation of its amino groups in water which makes lignin positively charged, and thereby very attractive for flocculation and different kinds of binding applications. Since most natural colloidal particles, including organic matter, bacteria and macromolecules, are negatively charged attractive electrostatic interactions may lead to flocculation. Besides modified lignin, possess positively charged groups due to the creative amino group. Therefore, the modified lignin can remove organic matter, colloidal silica and some inorganic elements from water.

Table (4): Comparison between modified lignin and ferric chloride doses on the removal of organic matter, turbidity, hardness and total silica of water

\begin{tabular}{|c|c|c|c|}
\hline Parameters & Raw water & $\begin{array}{c}\text { Water clarified by } \\
\mathbf{3 5} \mathbf{~ p p m} \\
\text { Ferric chloride }\end{array}$ & $\begin{array}{c}\text { Water clarified by } \\
\mathbf{6} \mathbf{~ p p m ~ M o d i f i e d ~ l i g n i n} \\
\mathbf{+ 2 0} \mathbf{~ p p m ~} \mathbf{~ F e ~} \mathbf{~ I C ~}_{\mathbf{3}}\end{array}$ \\
\hline \hline $\mathrm{pH}$ & 8 & 7.49 & 7.67 \\
\hline Turbidity NTU & 18.2 & 2.3 & 1.1 \\
\hline Total hardness ppm & 149 & 100 & 90 \\
\hline Ca hardness ppm & 81.6 & 45 & 41 \\
\hline Organic matter ppm & 11.05 & 7.9 & 4.14 \\
\hline Total silica ppm & 20.92 & 18.1 & 17.98 \\
\hline
\end{tabular}


Also figure (11) show the shape and size It is clearly seen that the size of flocs when using modified lignin is much higher than that formed when using ferric chloride or alum. Nevertheless, the time of floc formation and steeling time is better when using modified lignin with ferric chloride.

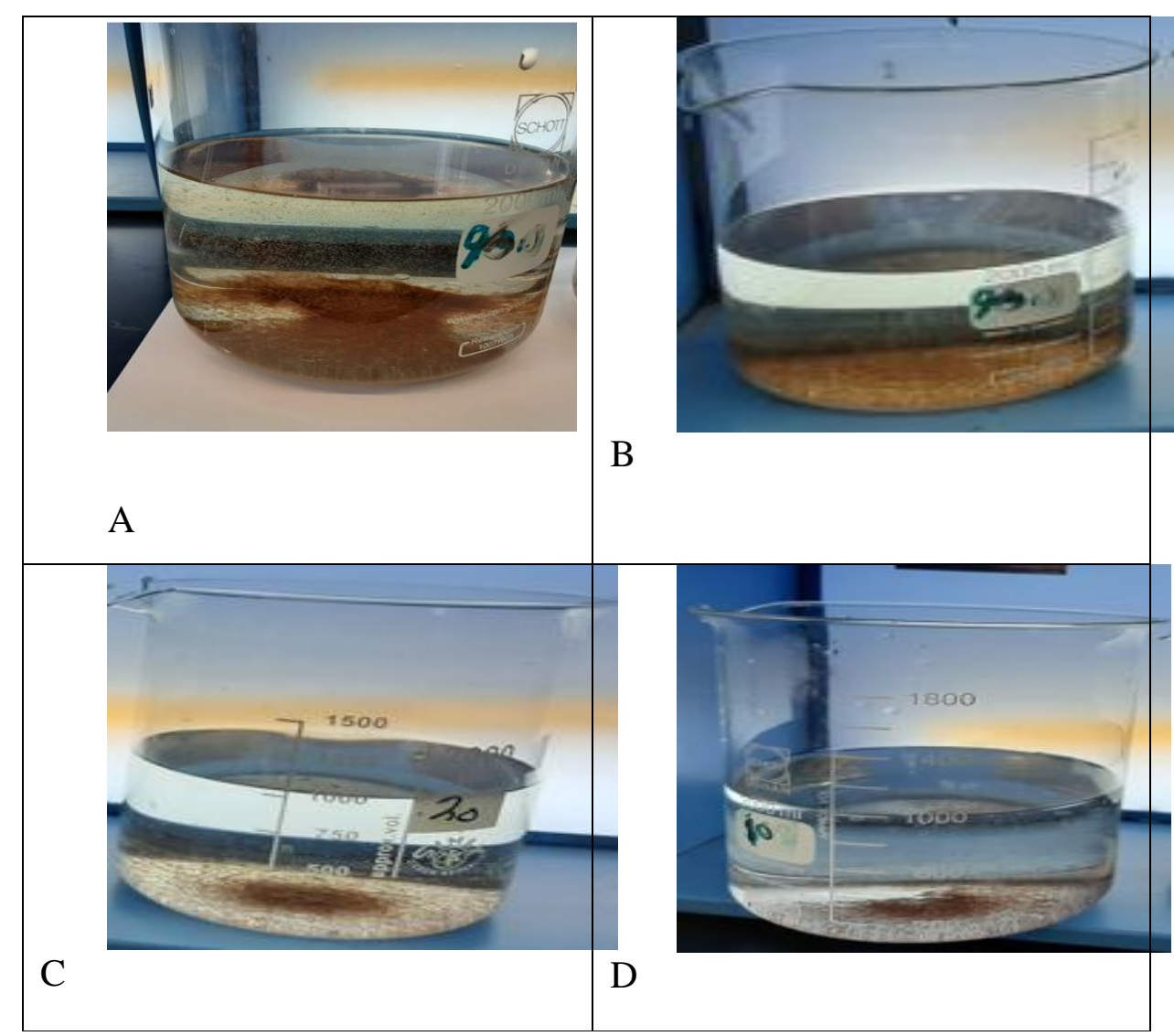

Figure (11): The floc formation at $\left(35 \mathrm{ppm} \mathrm{FeCl}_{3}\right.$ for $\mathrm{A}, 20 \mathrm{ppm} \mathrm{FeCl}_{3}+$ 2ppm modified lignin for $\mathrm{B}, 20 \mathrm{ppm} \mathrm{FeCl}_{3}+4 \mathrm{ppm}$ modified lignin for $\mathrm{C}$ and 20ppm $\mathrm{FeCl}_{3}+6 \mathrm{ppm}$ modified lignin for D) 
Table (5) shows the effect of adding combination of ferric chloride and modified lignin to the industrial wastewater with different concentration of ferric chloride and amount of modified lignin injection at $4 \mathrm{ppm}$.

Table (5): The jar test results of different dose of ferric chloride and modified lignin concentration

\begin{tabular}{|c|c|c|c|c|c|c|c|}
\hline $\begin{array}{c}\mathrm{FeCl}_{3} \text { Injection } \\
(\mathrm{ppm})\end{array}$ & Industrial & 5 & 10 & 15 & 20 & 25 & 35 \\
\hline $\begin{array}{l}\text { Modified lignin } \\
\text { Injection mg/liter }\end{array}$ & waste water & 4 & 4 & 4 & 4 & 4 & Zero \\
\hline Turbidity NTU & 18.2 & 1.32 & 1.28 & 1.01 & 1.1 & 1.15 & 2.3 \\
\hline $\begin{array}{c}\text { Total Alkalinity } \\
\text { ppm }\end{array}$ & 121 & 119 & 117 & 115 & 112 & 110 & 116 \\
\hline $\begin{array}{c}\text { Organic Matter } \\
\text { ppm }\end{array}$ & 17.3 & 6.57 & 6.58 & 6.75 & 5.11 & 5.11 & 7.9 \\
\hline Total Silica ppm & 21.81 & 17.32 & 16.52 & 16.35 & 15.38 & 15.39 & 20.1 \\
\hline
\end{tabular}

It's clearly seen that the best does of ferric chloride is $20 \mathrm{ppm}$ at $4 \mathrm{ppm}$ modified lignin which gives maximum removal of turbidity, organic matter and total silica.

The work was extended to identify the optimum doses of modified lignin by changing the ferric chloride dose in small range $(20,22,24,26$ and 28ppm). Table (6) shows the results of jar test while changing the $\mathrm{FeCl}_{3}$ concentration from 20 to $28 \mathrm{ppm}$ and fixing modified lignin injection to 4 ppm. It was observed that the best clarification was at $26 \mathrm{ppm}$ ferric chloride and 4 ppm modified lignin. This combined dose gives the lowest values of turbidity, total alkalinity, organic matter and colloidal silica. 
Table (6): The jar test results of different doses of $\mathrm{FeCl}_{3}$ and modified lignin

\begin{tabular}{|c|c|c|c|c|c|c|}
\hline Ferric chloride injection (ppm) & \multirow{2}{*}{$\begin{array}{c}\text { Raw } \\
\text { water }\end{array}$} & 20 & 22 & 24 & 26 & 28 \\
\cline { 1 - 5 } $\begin{array}{c}\text { Modified lignin Injection } \\
\text { mg/liter }\end{array}$ & 18.2 & 1.1 & 1.15 & 1.19 & 0.97 & 0.99 \\
\hline Turbidity NTU & 121 & 112 & 111 & 110 & 107 & 107 \\
\hline Total Alkalinity ppm & 17.3 & 5.11 & 8.68 & 8.12 & 7.15 & 7.18 \\
\hline Organic Matter ppm & 21.81 & 15.38 & 17.84 & 15.35 & 10.89 & 11.16 \\
\hline Total Silica ppm & &
\end{tabular}

\section{Heavy metal removal by modified lignin:}

Industrial effluents may contain a mixture of heavy metal ions, and therefore, testing of chelation is recommended for the obtained modified lignin as ion chelating agent. Thus, the adsorption of the metal ions $\mathrm{Zn}, \mathrm{Pb}$, $\mathrm{Fe}, \mathrm{Ni}$, and $\mathrm{Cd}$ by the modified lignin was studied by using atomic absorption technique for measuring the examined metals in water. The effect of modified lignin concentrations $(2,4,6,8 \mathrm{mg} / \mathrm{l})$ on the removal of such elements from water was studied. Figure (12) show that the modified lignin has high efficiency for removal of elements. For instance, as much as $75 \%$ of $\left(\mathrm{Ni}^{2+}\right.$, $\left.\mathrm{Zn}^{2+}, \mathrm{Co}^{2+}, \mathrm{Cd}^{2+}, \mathrm{Mn}^{2+}\right)$ were removed by using ( $\left.8 \mathrm{ppm}\right)$ of modified lignin, and 95\% removal of ( $\mathrm{Fe}$ and $\mathrm{Cu}$ ). Also it's clearly seen from Figure (12), that the increment of modified lignin accompanied by decrement of metal ions in water to be examined reaching to complete removal of metals ions at ( 8 $\mathrm{mg} / \mathrm{l})$. 


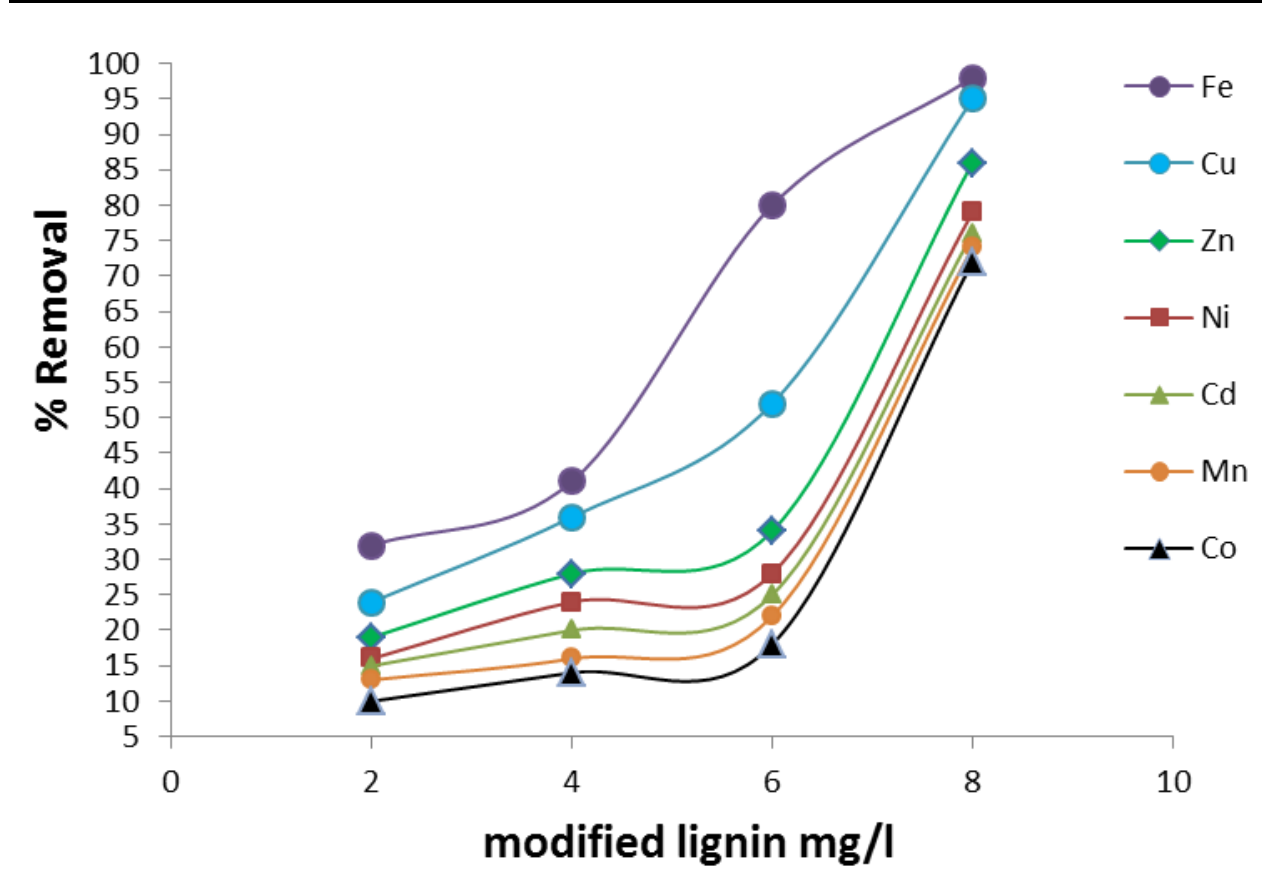

Figure (12): Effect of modified lignin dose on heavy metal removal

\section{REFERENCES}

Abd Elwahab, M. I.; Hafez, A. I.; Tera, F. M.; El-Nagar, K. I.; Abou Elmagd, W.S.I. and Hashem, A. I. (2018): Carbamated corn cobs as a natural coagulant for water treatment. International Journal of Advanced Scientific and technical Research 4 (8), 74-84.

Alkadi, M.Y.; Razek, T.; Hafez, A.I. and Moursy, M.E. (2015): Cationic modified rice starch for drinking water purification. Journal of Advanced Scientific Research 6 (2), p 10-13.

Ali, I. and Gupta, V. K (2006): Advances in water treatment by adsorption technology. Nature protocols 1, 2661. 
Al-Asheh, S. and Duvnjak, Z. (1997): Sorption of cadmium and other heavy metals by pine bark. J. Hazard Mater, 56, 35-51.

Anwar Ma'ruf; Bambang, P. and Nita, A. (2004): Lignin Isolation Process from Rice Husk by Alkaline Hydrogen Peroxide: Lignin and Silica Extracted" International Conference on Chemistry, Chemical Process and Engineering (IC3PE)2017AIP Conf. Proc. 1823, 020013-1-020013-5.

Babel,S. and Kurniawan,T.A.(2003): Low-cost adsorbents for heavy metals uptake from contaminated water: a review. J. hazardous materials 97,219-243.

Crini, G. Non-conventional (2006): Low-cost adsorbents for dye removal": A review. Bioresource technology 97, 1061-1085.

Crist, D. R.; Crist, R. H. and Martin J. R. (2003): A new process for toxic metal uptake by a kraft lignin. J Chem Technol Biotechnol., 78, 199-202.

Demirbas A. (2004): Adsorption of lead and cadmium ions in aqueous solutions onto modified lignin from alkali glycerol delignication. J. Hazard Mater B, 109, 221-226.

El-Kareish, G.M.; Hafez, A.I. and Tera, F.M. (2019): Improving Petroleum Industrial Waste Water Quality Using Cationic Modified Rice Starch. International Journal of Chemical Sciences 16 (4), 1-9.

El-Sayed, G.O; Hafez, A. I. and Zahr El-Deen, H. M. (2016): Extraction of Calcium and magnesium ions from Water-Treatment-Plant Sludge for Reusing in industrial water Treatment. International Journal of Advanced Scientific and Technical Research vol.6, Issue (5) pp 492-510. 
Fanta, G. F.; Burr, R. C.; Russell, C. R. and Risl, C. E. (1970): Graft copolymers of starch and poly (2-hydroxy-3 methacryloyloxy propyl trimethyl-ammonium chloride); Preparation and testing as flocculating agents. Journal of Applied Polymer Science, 14, 2601-2609.

Gabaldon C., Marzal P., Ferrer J., Seco A. (1996) "Single and competitive adsorption of $\mathrm{Cd}$ and $\mathrm{Zn}$ onto granular activated carbon", Water Res., 30, 3050-3060.

Goheen, D. W. (1978): Chemicals from Lignin. CRC press, Boca Raton, FL, 143-161.

Guo, X. X.; Shu, F. Z.; Ben, Z. J. and Jin, Z. Y. (2006): Microwave-assisted synthesis of starch maleate by dry method. Starch-Strake, 58, 464-467.

Hao, X. K.; Chang, Q.; Duan, L. L. and Zhang, Y. Z. (2007): Synergetically acting new flocculants on the basis of starch-graftpoly(acrylamide)-co-sodium xanthatc. Starch-Strake, 59,251-257.

Heinzc, T.; Haaek, V. and Rensing, S. (2004): Starch derivatives of high degree of functionalization. Starch-Strake, 56, 288-296.

Hafez, A. I.; Tera, F. M. and El-Shereafy, E. E. (2014): Synthesis and application of cationic rice starch as a flocculant for water treatment. Inter J Adv Sci and Tech Res. 46, 156-68.

Ismail, H. M.; Hafez, A. I.; Khalil, N. A. and Hashem, A. I. (2019): Using of untreated and thermally treated kaolin clay as adsorbent and coagulant in the treatment of Wastewater. Journal of Applied Chemistry (IOSR-JAC 12 (9), 39-51.

Jacrnstrocm, L.; Lason, L. and Rigdahi, M. (1995): Flocculation in Kaolin suspension induced by modified starches. 2. Oxidized and hydrophobically modified starch in comparison with poly (vinyl alcohol) and carboxymcthyl cellulose. Colloids and Surfaces A: Physicochemical and Engineering Aspects, 104, 207-216. 
Kadirvelu, K.; Faur-Brasquet, C. and Le Cloirec, P. (2000): Removal of $\mathrm{Cu}(\mathrm{II}), \mathrm{Pb}(\mathrm{II})$ and $\mathrm{Ni}(\mathrm{II})$ by adsorption onto activated carbon cloths. Langmuir, 16, 8404-8409.

McKay G. and Porter J. F. (1997): Equilibrium parameters for the sorption of copper, cadmium and zinc ions on peat. J. Chem. Technol Biotechnol ,69,309-320.

Mohan D. and Chander S. (2006): Single, binary, and multicomponent sorption of iron and manganese on lignite. J. Colloid Interface Sci., 299, 76-87.

Moreno-Castilla, C.; Alvarez-Merino, M. A.; Lopez-Ramon M. V. and Rivera-Utrilla J. (2004): Cadmium ion adsorption on different carbon adsorbents from aqueous solutions. Effect of surface chemistry, pore texture, ionic strength and dissolved natural organic matter. Langmuir, 20, 8142-8148.

Morton, J.; Adler, E.; Marton, T. and Falkehag, S. I. (1966): Lignin Structure and Reactions. Advances and Chemistry Series, 59, 125.

Orhan, Y. and Büyükgüngör, H. (1993): The removal of heavy metals by using agricultural wastes. Water Sci Tech, 28, 247-255.

Oubagaranadin, J. U. K. and Murthy, Z. V. P. (2009). Adsorption of divalent lead on a montmorillonite-illite type of clay. Ind Eng Chem Res, 48, 10627-10636.

Pal, S.; Mal, D. and Singh, R. P. (2005): Cationic starch: An effective flocculating agent. Carbohydrate Polymers, 59, 417-423.

Sanchez, A. G.; Ayuso, E. A. and Blas, O. (1999): Sorption of heavy metals from industrial waste water by low-cost mineral silicates. Clay minerals 34, 469-469.

Rogers, W. F. (1963): Compositions and Properties of Oil Well Drilling Fluids. $3^{\text {rd }}$ Ed. Gulf Publishing Comp. Houston, TX. 
Srivastava, S. K.; Singh, A. K. and Sharma, A. (1994): Studies on the uptake of lead and zinc by lignin obtained from black liquor- a paper industry waste material. Environ Technol, 15, 353-360.

Veli, S. and Alyüz, B. (2007): Adsorption of copper and zinc from aqueous solutions by using natural clay". Journal of hazardous materials $149,226-233$.

Suhas, P. J.; Carrott, M. and Ribeiro Carrott, M. L. (2007): Lignin - from natural adsorbent to activated carbon: a review. Bioresour Technol, 98, 2301-2312.

Ghaffar, S. H. and Fan, M. (2013): Review on "Structural analysis for lignin characteristics in biomass straw, journal of Biomass and Bioenergy, 57, 264-279.

Yalpani, .M. and Magdzlinsky, L. (1995): Lignin having nitrogen and sulfure and process therefore employing thiourea. united states patent no. $4,857,638$.

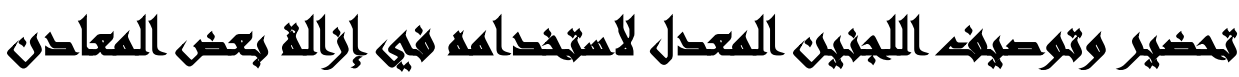

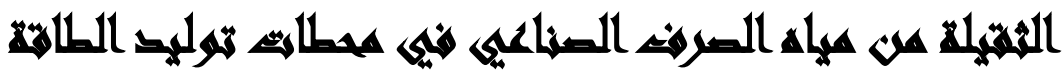

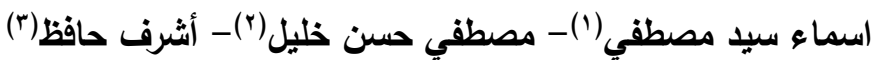

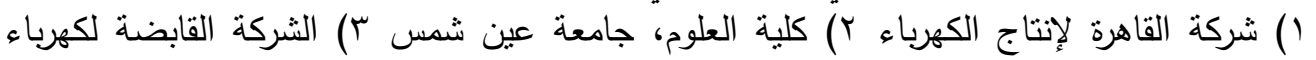

\section{المستيلصن}

في هذا البحث تم تحضير مشتق اللجنين القابل للذوبان الذي يحتوي على مجموعة أمينية بواسطة تقنية تعتمد على الطريقة الجافة عن طريق تفاعل اللجنين المستخلص من أوراق الجوافة مع التع

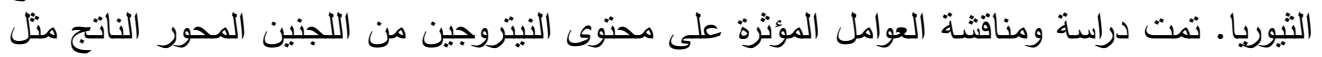


درجة حرارة التفاعل -زمن التفاعل -تركيز هيدروكسيد الصوديوم إلى جانب نركيز الثيوريا. حيث

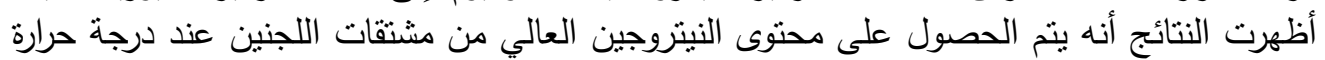

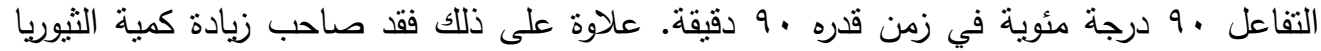

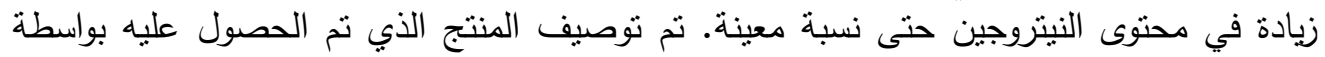
FT-IR

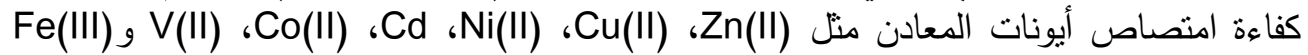

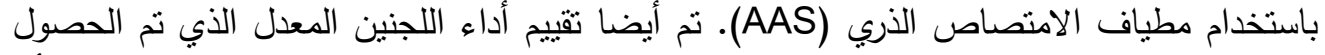

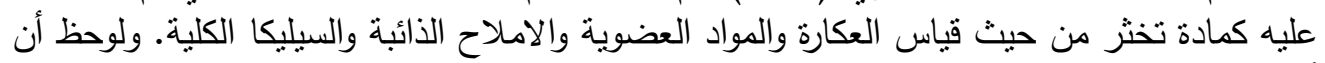

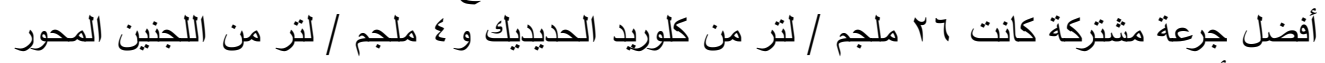

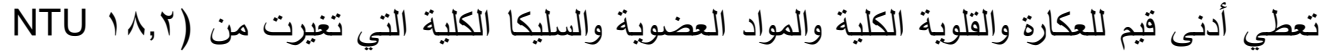

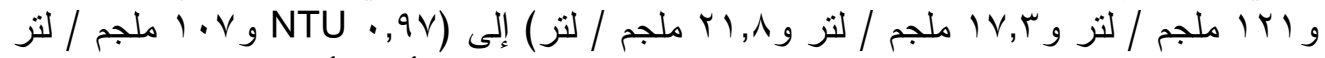

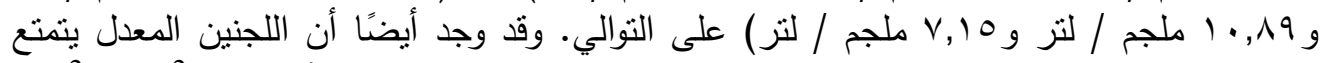

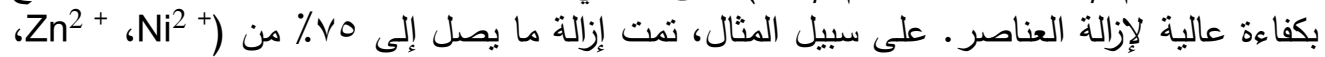
و و $\cdot\left(\mathrm{Cu} 2^{+}, \mathrm{Fe}^{3+}\right)$ الكلمات الدالة: اللجنين المحور - مواد تخثر - إزالة المعادن الثقيلة - معالجة المباه. 